drawings, but a more helpful approach would have been achieved by adding labels to the diagrams. In the seeds of the Violaceae, for example, one can talk of elaiosomes and their function in dispersal, but it would help to have a detailed drawing with an appropriate label. The diagrams are, however, generally well chosen and informative; they lack the striking, aesthetic appeal and full vegetative detail of those in Heywood's book, but they make up for this in precision and clarity.

This book will become a vital and valued tool to those botanists, both amateur and

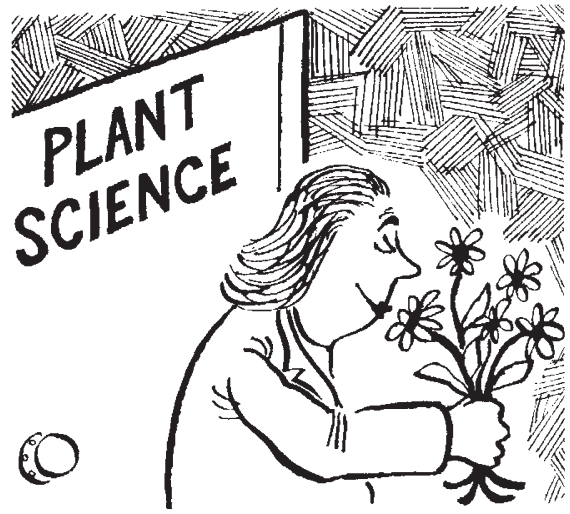

professional, who wish to look more closely at the structure of easily available flowers.

O'Brien and McCully's book is also concerned with observational techniques, but is evidently intended both for teaching and research. It is essentially a laboratory manual of microscopic, anatomical and morphological methods, giving both theoretical background and practical instruction. It begins from first principles of microscopy and has a "cook-book" approach with some very helpful and informal marginal comments, such as, "If you cannot budge something with finger and thumb ... before exerting your strength, ASK!". Very clearly aimed at the undergraduate! This chatty style, accompanied by lucid explanations of principle and practice should prove very helpful, especially in such areas as phase contrast and interference contrast microscopy. The language used avoids unnecessary jargon and has many hints for trouble-shooting and image improvement. Chapters on specimen preparation and microphotography for both light and electron microscopy are included. However, the format and sub-heading numbering demand serious criticism; what is otherwise an agreeably usable book is given an unduly forbidding appearance by a complex cross-referencing system and an ugly off-set litho production.

Both of these books seek to reach a small, and still shrinking market. They will serve this market well, but whether they will succeed in reversing its slow demise is questionable.

Peter D. Moore is Senior Lecturer in the Department of Plant Sciences, King's College, University of London.

\section{Panglossian botany}

\section{J.L. Harper}

Physiological Plant Ecology, 2nd Edn. By W. Larcher. Pp.303. ISBN 0-387-09795-3. (Springer-Verlag: 1980.) DM59, \$34.90. Environmental Physiology of Plants. By A.H. Fitter and R.K.M. Hay. Pp.355. Hbk ISBN 0-12-257760-4; pbk ISBN 0-12257762-0. (Academic: 1981.) Hbk £19.60, $\$ 47.50$; pbk $£ 7.95$, \$19.50.

"PlANT ecophysiology, a discipline within plant ecology, is concerned fundamentally with the physiology of plants as it is modified by fluctuating external influences" (Larcher). "How do the intricate physiological mechanisms which have been elucidated over the last 100 years by plant physiologists really operate under natural conditions?"' (Fitter and Hay). These sentences define the scope of these two books and at the same time relegate the rest of plant physiology (that which is not "eco-") to the study of plants in constant and perhaps irrelevant conditions.

It is easy to recognize a text in environmental or eco-physiology by the high frequency of the words "adaptation" and "stress". Counting their occurrences and guessing their meanings in different contexts is a fascinating exercise. I suspect that to most ecophysiologists adaptation is that feature of an organism that may be explained away as "a good thing". It is, then, a comfort that the word carries the guesstimate that such properties are the result of all-powerful natural selection which has sought out the optimal solutions to the problems set by nature. It then remains the task of the ecophysiologist to demonstrate just how everything about his organisms is for the best in the best of all possible worlds.

Stress is, of course, a "bad thing". Sometimes it is a nasty stimulus, sometimes an uncomfortable response. Fitter and Hay don't like the word because it lacks the precision given to it in mechanics - yet, use it 22 times on one page. (Stress is not in the index, though strain is.) To Fitter stress appears to be a stimulus, a force imposed by the environment, but to his co-author the word appears to mean response - a state induced in the organism: "Plant cells ... at a turgor pressure lower than the maximum value are said to be suffering from Water Stress". To Larcher "stress is the exposure to extraordinarily unfavourable conditions" - clearly to him it is a stimulus, not a response and must be extreme. I also puzzled about Fitter and Hay's phrase "low light stress" but suppose it is a synonym for "shade stress"!

These two books cover very similar ground - the responses of plants to light, water, nutrients, temperature (and for Fitter and Hay the effect of animals and some microorganisms). Fitter and Hay are more interested in cellular and biochemical processes than Larcher, who is more con- cerned with the whole plant and its contribution to community processes. Fitter and Hay include a section on allelopathy in which they accept uncritically some very dubious evidence.

Both books carry an extensive bibliography and between them cite more than 1,500 references, of which only about 50 are quoted in both. Together they give a splendid introduction to the literature. Fitter and Hay's is a very Anglo-American text (less than $5 \%$ of the references are in alien tongues). Larcher's bibliography is international, as befits an author who advises "Despite the difficulties it is worth taking the trouble to read original works in that language in which the author can express himself most precisely". Is this a warning to those who are reading his own book in its excellent translation?

Students could be expected to read and enjoy chapters in Larcher and not become too badly infected with teleology and Panglossian optimism. However, as regards Fitter and Hay, I admit to a bias: I cannot stomach phrases such as ". . . respiration has a purpose ..."; ". . . the various mechanisms that have been adopted to fit the species [sic] to their environment"; "plants appear to use it [phytochrome] to detect shading"; "species [sic] . . . may need to maximise plastic responses to permit offspring to colonise a wide range of habitats . ..". I must stint my praise for a book that seems to present biology as a study of purposeful and soothsaying species like football managers planning their future goals.

J.L. Harper is Head of the School of Plant Biology at the University College of North Wales, Bangor.

\section{Renewed growth of plants}

\section{James F. Sutcliffe}

Growth and Differentiation in Plants, 3rd Edn. By P.F. Wareing and I.D.J. Phillips. Pp.343. Hbk ISBN 0-08-026351-8; pbk ISBN 0-08-026350-X. (Pergamon: 1981.) Hbk $£ 20, \$ 40$; pbk £9, \$20.

THIS popular textbook, which was published first in 1970 and reprinted several times before the second edition appeared in 1978, has now hid another face-lift. Apart from a shortening of the title - which does not indicate any change in approach there is a new format with double-column printing on a larger folio size. Even the flowering shoot of Plumbago indica which continues to decorate the front cover appears to have had a new lease of life. The plant has turned green again and several new leaves have appeared. 